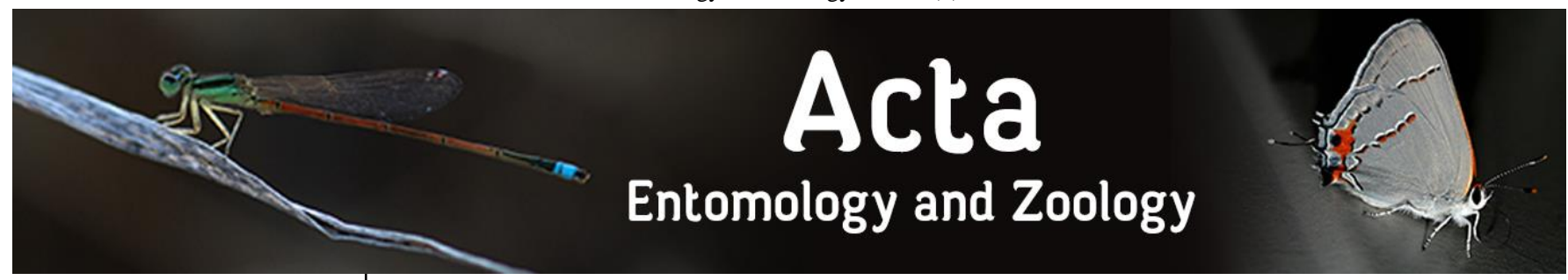

E-ISSN: 2708-0021 P-ISSN: 2708-0013 www.actajournal.com AEZ 2021; 2(1): 05-11 Received: 04-10-2020 Accepted: 06-12-2020

Victor Joly DZOKOU University of Dschang, Faculty of Agronomy and Agricultural Sciences, Phytopathology and Agricultural Zoology Research Unit, Dschang, Cameroon

Nicaise LONTCHI FOFE University of Dschang, Faculty of Agronomy and Agricultural Sciences, Phytopathology and Agricultural Zoology Research Unit, Dschang, Cameroon

\section{Aoudou YAOUBA}

University of Dschang,

Faculty of Agronomy and

Agricultural Sciences,

Phytopathology and

Agricultural Zoology Research

Unit, Dschang, Cameroon

Lucien Dieudonné BITOM OYONO

University of Dschang, Faculty of Agronomy and Agricultural Sciences, Department of Soil Science, Dschang, Cameroon

Joseph Lebel TAMESSE University of Yaoundé I, Higher Teachers' Training College, Laboratory of Zoology, Yaoundé, Cameroon

Corresponding Author: Victor Joly DZOKOU University of Dschang, Faculty of Agronomy and Agricultural Sciences, Phytopathology and Agricultural Zoology Research Unit, Dschang, Cameroon

\section{Entomofauna of sweet pepper (Capsicum annuum L.) in Menoua division, Western Cameroon}

\section{Victor Joly DZOKOU, Nicaise LONTCHI FOFE, Aoudou YAOUBA, Lucien Dieudonné BITOM OYONO and Joseph Lebel TAMESSE}

DOI: https://doi.org/10.33545/27080013.2021.v2.i1a.23

\begin{abstract}
Pepper production in Cameroon faces many constraints, including arthropods, which occupy one of the most important places. This study was conducted with the aim of gathering information on the entomofauna of peppers for better decision-making on control methods. To achieve this, an inventory of arthropods in 4 localities in the Menoua pepper production basins was carried out on the "Simbad, "Tibesti" and "Ylusse" varieties. Insects captured weekly using an entomological net and a mouth aspirator were identified in the Agricultural Zoology Laboratory at the University of Dschang. The results showed that insects associated to peppers varied in number and diversity from one locality to another. A total of 4003 Insecta and Arachnida were captured. The Insecta class has 9 orders (Coleoptera, Diptera, Hemiptera, Hymenoptera, Thysanoptera, Lepidoptera, Odonata, and Orthoptera) of 85 families. The Order of the Hemiptera is the most representative in terms of individuals (1627) and that of the Diptera the most representative in number of families (27). Pearson's X-squared test shows a significant dependence between different orders of arthropods and the 3 varieties of peppers. The "Simbad" variety proved to be the most sensitive with $48.31 \%$. Although most of these insects are pepper pests, there have been some pollinators, predators and parasitoids. The data collected provide a preliminary basis for any biological or integrated pest management against Capsicum annuum pests in Menoua-Cameroon.
\end{abstract}

Keywords: Entomofauna, Capsicum annuum, insecta, pest, auxiliary

\section{Introduction}

Market gardening is one of the most productive agricultural systems in Africa (FAO, 2012) [11]. It plays a key role in most nutrition and anti-poverty programmes. They contribute significantly to family incomes (Yolou, 2015) ${ }^{[28]}$. Pepper among vegetable crops is one of the most widely consumed vegetables in the world and in Africa. It is a vegetable fruit widely consumed throughout the world mainly as a spice. Pepper fruits are a source of vitamins (A, D, E, C, K, B2), protein, fat, carbohydrates, fibre and minerals $(\mathrm{Ca}, \mathrm{P}, \mathrm{Fe})$. They are rich in potassium, flavonoids and cardiovascular antioxidants. This wealth helps in the prevention of many diseases such as cancer and cardiovascular disease (Wilcox et al., 2004) [26]

The increase in the urban population and the onset of the economic crisis have led to an unprecedented boom in market gardening activity in urban and periurban areas in Cameroon (Bopda, 2003) ${ }^{[2]}$. In the west region of the country, a predominantly agricultural region, there have been profound changes in recent decades as a result of the consequences of coffee sales (Fouepe, 2008) ${ }^{[13]}$. As part of the conversion of this coffee economy, the former producers of Arabica coffee have gradually converted into vegetable growers (Kaffo, 2005) [19]. For this purpose, crops such as potatoes, tomatoes, carrots, peppers have emerged (Tchékoté et al., 2018) ${ }^{[23]}$. The intensification of this activity goes hand in hand with a diversification of pests (Albert et al., 2003) ${ }^{[1]}$, resistance to pesticides and formerly specialized insect species, have passed over several crops (Djiéto and Aléné, 2006) ${ }^{[9]}$. Pest arthropods often pose real problems for producers with damage (Diatte et al., 2016) ${ }^{[7]}$. In an effective control program, the preliminary step to successfully protecting this culture is knowledge of enemies (Chougourou et al., 2012) ${ }^{[4]}$. It is for this reason that this study proposes to invent the entomofauna of the sweet pepper fields in order to consider an effective and sustainable plant protection of this crop in Cameroon. 


\section{Materials and Methods \\ Collecting locations and history}

The collections took place in 3 localities in the Nkong-Ni district (Tetop: $2050 \mathrm{~m}^{2}, 3$ varieties, 10 ${ }^{\circ} 11^{\prime} 70.2^{\prime \prime} \mathrm{E}$ and $5^{\circ} 42^{\prime} 32.1$ "N; Zaah Seeh: $1244 \mathrm{~m}^{2}, 3$ varieties, 10¹0'76.5"E and $5^{\circ} 44^{\prime} 78.11^{\prime \prime} \mathrm{N}$; Lepeh: $600 \mathrm{~m}^{2}$, "Simbad" variety under cover, $10^{\circ} 05^{\prime} 08.9^{\prime \prime} \mathrm{E}$ and $5^{\circ} 31^{\prime} 59.8^{\prime \prime} \mathrm{N}$ ) and a locality in the district of Dschang (Municipal Lake: $30 \mathrm{~m}^{2}$, "Simbad" variety, $10^{\circ} 06^{\prime} 46.3^{\prime \prime E}$ and $5^{\circ} 44^{\prime} 96.8^{\prime \prime N}$ ), Menoua Division, $1385 \mathrm{~m}$. Amendments and Chemical were made indiscriminately to peppers by producers, except in Municipal Lake where the crop was organic.

\section{Capture and conservation of arthropods}

These activities took place over a period from February to March 2019. Arthropods associated to the cultivation of peppers were captured using an entomological net. Arthropods were randomly mowed on pepper plants in all plots. The arthropods that had fallen into the net were recovered using the mouth aspirator. The soft-bodied, unmoved individuals found on the plant's organs were recovered with the brush so as not to damage them. The larger ones were directly introduced into the $70 \%$ alcohol containing pillboxes. Catches were made in each plot once a week between 9 a.m. and 10 a.m. when the dew completely disappeared. The collected specimens were kept in $70 \%$ alcohol and taken to the laboratory for counting and identification.

\section{Sorting and identifying arthropods}

This stage took place from April to June 2019. The specimens captured and stored in $70 \%$ ethanol were taken to the Agricultural Zoology Laboratory at the University of Dschang. The arthropods were spread out for better observation on Motic brand binocular magnifying glass. The specimens were initially separated in order according to their morphological characteristics and counted. Using the identification keys of Delvare and Aberleng (1989) [5], Wolfgang and Werner (1992) ${ }^{[27]}$ and the entomological collection of the Agricultural Zoology Laboratory at the University of Dschang, the families were determined. These specimens are kept in $70 \%$ ethanol at the Laboratory of Agricultural Zoology at the University of Dschang (LAZUDs).

\section{Statistical analysis}

All data collected was stored in Microsoft's Excel 2010 software. The Pearson's Chi-squared

Test was used to analyse the data.

\section{Results}

The arthropods caught between February and April 2019 in the pepper fields are numerous and diverse. A total of 4.003 arthropods were collected from the different pepper plots in the 4 localities surveyed. These arthropods belong to the Arachnida and the Insecta class. The "Simbad" variety proved to be the most sensitive with $48.31 \%$ (Table 1). Indeed, in Lepeh, only the "Simbad" variety is cultivated. In the localities of Zaah Seeh and Tetop, the 3 varieties of sweet pepper were cultivated. The Arachnida class is represented by one family. The insect class is made up of 9 orders, namely, Diptera, Coleoptera, Hemiptera, Lepidoptera, Orthoptera, Hymenoptera, Thysanoptera, Mantoptera and Odonata.

Table 1 shows that Hemiptera order is the most represented in individuals followed by the Order of Diptera. Pearson's $\mathrm{X}$-squared test shows a very significant dependence between the different orders of arthropods and the different locations where the collections took place $\left(\mathrm{p}\right.$-value $\left.<2.2 \mathrm{e}^{-16}\right)$. Similarly, Pearson's X-squared test shows a very significant dependence between different orders of arthropods and the 3 varieties of sweet peppers (Table 2).

Table 1: Percentage of specimens of the various orders according to the 4 localities of collection

\begin{tabular}{|c|c|c|c|c|c|c|c|c|c|c|}
\hline \multirow{3}{*}{$\begin{array}{c}\text { Localities } \\
\text { Orders }\end{array}$} & \multicolumn{6}{|c|}{ Nkong-Ni } & \multirow{2}{*}{\multicolumn{2}{|c|}{$\begin{array}{c}\text { Dschang } \\
\text { Municipal Lake }\end{array}$}} & \multirow{2}{*}{\multicolumn{2}{|c|}{ Total }} \\
\hline & \multicolumn{2}{|c|}{ Zaah Seeh } & \multicolumn{2}{|c|}{ Tetop } & \multicolumn{2}{|c|}{ Lepeh } & & & & \\
\hline & NI & $\%$ & NI & $\%$ & NI & $\%$ & NI & $\%$ & NI & $\%$ \\
\hline Coleoptera & 145 & 0.14 & 44 & 1.13 & 156 & 0.01 & 30 & 1.38 & 375 & 2.66 \\
\hline Diptera & 668 & 10.26 & 275 & 2.55 & 437 & 14.76 & 73 & 0.09 & 1453 & 27.66 \\
\hline Hemiptera & 450 & 9.99 & 240 & 0.33 & 856 & 11.68 & 81 & 0.13 & 1627 & 22.13 \\
\hline Hymenoptera & 33 & 2.68 & 24 & 0.00 & 80 & 1.03 & 16 & 2.11 & 153 & 5.82 \\
\hline Lepidoptera & 52 & 0.74 & 17 & 0.02 & 42 & 0.23 & 3 & 0.46 & 114 & 1.45 \\
\hline Orthoptera & 1 & 1.35 & 4 & 0.13 & 11 & 0.43 & 2 & 0.32 & 18 & 2.23 \\
\hline Thysanoptera & 0 & 6.80 & 0 & 2.94 & 65 & 14.64 & 0 & 1.00 & 65 & 25.38 \\
\hline Mantoptera & 0 & 0.21 & 0 & 0.09 & 2 & 0.45 & 0 & 0.03 & 2 & 0.78 \\
\hline Odonata & 1 & 0.03 & 0 & 0.09 & 1 & 0.01 & 0 & 0.03 & 2 & 0.16 \\
\hline Arachnida & 111 & 6.55 & 29 & 0.03 & 44 & 5.07 & 10 & 0.00 & 194 & 11.65 \\
\hline Total & 1461 & 38.75 & 633 & 7.31 & 1694 & 48.31 & 215 & 5.55 & 4003 & 99.92 \\
\hline
\end{tabular}

Pearson's Chi-squared test: $\mathrm{X}$-squared $=348.58, \mathrm{df}=27, \mathrm{p}$-value $<2.2 \mathrm{e}^{-16}$;

$\mathrm{NI}=$ Number of Individuals

The nine orders include 85 families. The number of families varied in the different orders of insects. The order of the Diptera counts the largest number ( 27 families) followed by the order of Hymenoptera (19 families) and Hemiptera (15 families). The least represented orders are the Orthoptera (5 families), Mantoptera and the Odonata, who each have one family. 
Table 2: Percentage of specimens of the various orders according to the 3 varieties of sweet peppers

\begin{tabular}{|c|c|c|c|c|}
\hline \multirow{2}{*}{ Orders } & \multicolumn{3}{|c|}{ Varieties } & \multirow{2}{*}{ Total } \\
\cline { 2 - 4 } & Simbad & Ylusse & Tibesti & 0.64 \\
\hline Coleoptera & 0.18 & 0.24 & 0.22 & 25.93 \\
\hline Diptera & 7.15 & 10.13 & 8.64 & 23.73 \\
\hline Hemiptera & 6.44 & 6.23 & 11.06 & 3.48 \\
\hline Hymenoptera & 0.27 & 2.92 & 0.29 & 21.32 \\
\hline Lepidoptera & 1.61 & 1.65 & 18.07 & 0.51 \\
\hline Orthoptera & 0.02 & 0.39 & 0.10 & 11.87 \\
\hline Thysanoptera & 3.28 & 4.39 & 4.20 & 0.37 \\
\hline Mantoptera & 0.10 & 0.14 & 0.13 & 1.07 \\
\hline Odonata & 0.07 & 0.88 & 0.13 & 11.08 \\
\hline Arachnidae & 1.52 & 9.47 & 0.08 & 99.98 \\
\hline Total & 20.62 & 36.44 & 42.92 & \\
\hline
\end{tabular}

Pearson's Chi-squared test: $X$-squared $=208.63, \mathrm{df}=18, \mathrm{p}$-value $<2.2 \mathrm{e}^{-16}$

\section{Order Hemiptera}

The Order of the Hemiptera comprises 15 families (Table 3) present on the pepper in Dschang. The locality of Lepeh and Zaah seeh have the same number of families represented (12 families). The Miridae and Cydnidae families are present in Zaah seeh and are absent Lepeh and Lake. In addition, the Miridae, Psyllidae and Nepidae are absent only at the lake.
The Issidae family is only seen at Lepeh. The largest family is the Aphididae followed by ciccadellidae and Aleyrodidae. The least represented families are those of the Issidae and the Cydnidae. There is a significant difference between the Aleyrodidae, Aphididae, Ciccadellidae and Pyrrochoridae families in Tetop.

Table 3: Percentage of specimens of the different families of Hemiptera order according to the 3 varieties of sweet peppers

\begin{tabular}{|c|c|c|c|c|}
\hline \multirow{2}{*}{ Hemiptera } & Varieties & & \multirow{2}{*}{ Total } \\
\cline { 2 - 4 } & Simbad & Ylusse & Tibesti & \\
\hline Aleyrodidae & 1.04 & 2.28 & 2.01 & 5.33 \\
\hline Aphididae & 0.12 & 0.69 & 0.02 & 0.83 \\
\hline Beytilidae & 0.65 & 7.34 & 0.28 & 8.27 \\
\hline Ciccadellidae & 2.83 & 9.62 & 2.81 & 15.26 \\
\hline Ciccadidae & 1.39 & 3.95 & 1.89 & 7.23 \\
\hline Cydnidae & 0.53 & 0.93 & 1.27 & 2.73 \\
\hline Dinidoridae & 0.47 & 2.21 & 0.19 & 2.87 \\
\hline Issidae & 0.03 & 0.07 & 0.06 & 0.16 \\
\hline Miridae & 0.32 & 2.21 & 0.01 & 2.54 \\
\hline Nepidae & 0.12 & 0.80 & 0.00 & 0.92 \\
\hline Pentatomidae & 1.65 & 3.69 & 3.12 & 8.46 \\
\hline Psyllidae & 2.42 & 15.58 & 0.14 & 18.14 \\
\hline Pyrrochoridae & 0.60 & 5.26 & 0.03 & 5.89 \\
\hline Tingidae & 1.93 & 19.10 & 0.34 & 21.37 \\
\hline Total & 14.1 & 73.73 & 12.17 & 100 \\
\hline
\end{tabular}

Pearson's Chi-squared test: $X$-squared $=157.54, \mathrm{df}=26, \mathrm{p}$-value $<2.2 \mathrm{e}^{-16}$

\section{Order Diptera}

The Diptera order consists of 27 families listed on the pepper in the Menoua (Table 4), not all families have been represented in the four localities. In the Nkong-Ni district, the towns of Zaah seeh and Lepeh have the same number of families (22). The families of Ulididae, Chloropidae, Dolichopotidae and Sciaridae are present only in Lepeh. The Athericidae family is only found in Zaah Seeh and the
Otidae family is only in Tetop. The borough of Dschang has only 14 families. The most represented families are the Dosophilidae and the Hybotidae. There is a significant difference between the Cecidomyiidae, Drosophilidae and other families in Lepeh. There is a significant difference between the Drosophilidae family and all the families of the Diptera order in Zaah Seeh.

Table 4: Percentage of specimens of the different families of Diptera order according to the 3 varieties of sweet peppers

\begin{tabular}{|c|c|c|c|c|}
\hline \multirow{2}{*}{ Diptera } & Varieties & \multirow{2}{*}{ Ylusse } & \multirow{2}{*}{ Tibesti } & \multirow{2}{*}{ Total } \\
\cline { 2 - 2 } & Simbad & & & \\
\hline Agromyzidae & 1.31 & 0.56 & 1.96 & 3.83 \\
\hline Athericidae & 4.25 & 5.67 & 2.13 & 12.00 \\
\hline Apomyzidae & 0.94 & 0.85 & 0.80 & 2.60 \\
\hline Asilidae & 0.20 & 2.90 & 0.79 & 3.89 \\
\hline Bombyiidae & 0.002 & 0.36 & 0.27 & 0.63 \\
\hline Calliphoridae & 0.02 & 0.01 & 0.14 & 0.17 \\
\hline Cecidomyiidae & 3.22 & 3.67 & 2.05 & 8.93 \\
\hline Chloropidae & 1.35 & 1.21 & 1.15 & 3.71 \\
\hline Diopsidae & 0.60 & 1.36 & 0.08 & 2.04 \\
\hline
\end{tabular}




\begin{tabular}{|c|c|c|c|c|}
\hline & 0.13 & 0.12 & 0.11 & 0.37 \\
\hline Dolichopidae & 3.27 & 0.21 & 8.75 & 12.20 \\
\hline Drosophilidae & 0.02 & 1.08 & 0.64 & 1.75 \\
\hline Hybotidae & $2.95^{-03}$ & 2.91 & 3.44 & 6.35 \\
\hline Lauxaniidae & 1.22 & 0.65 & 1.61 & 3.47 \\
\hline Michiidae & $1.48^{-05}$ & 0.43 & 0.46 & 0.88 \\
\hline Muscidae & 0.31 & 0.24 & 0.30 & 0.84 \\
\hline Mycetophilae & $3.77^{-02}$ & 0.24 & 0.76 & 1.04 \\
\hline Otidae & 4.37 & 8.86 & 0.82 & 14.10 \\
\hline Phoridae & $5.93^{-02}$ & 0.67 & 0.14 & 0.87 \\
\hline Psyllidae & 0.21 & 0.12 & 0.27 & 0.59 \\
\hline Scatophagidae & 0.27 & 0.24 & 0.23 & 0.74 \\
\hline Sciaridae & 5.08 & 5.81 & 3.22 & 14.10 \\
\hline Sciomyzidae & $3.75^{-04}$ & 0.38 & 0.36 & 0.74 \\
\hline Syrphidae & $2.88^{-03}$ & 0.36 & 0.27 & 0.63 \\
\hline Tachninaire & 0.17 & 0.11 & 0.20 & 0.49 \\
\hline Tephritidae & $9.87^{-02}$ & 0.01 & 0.25 & 0.35 \\
\hline Tilupidae & 0.94 & 0.85 & 0.80 & 2.60 \\
\hline Ulididae & 26.42 & 39.88 & 33.61 & 99.91 \\
\hline Total & $0 f-52$ & &
\end{tabular}

Pearson's Chi-squared test: $\mathrm{X}$-squared $=154.37, \mathrm{df}=52, \mathrm{p}$-value $=4.397 \mathrm{e}^{-12}$

\section{Order Lepidoptera}

Seven families of the Order Lepidoptera are recorded on pepper in the Menoua (Table 5). The largest number of families is recorded in the Nkong-Ni district. The most represented family is that of the Gelichiidae followed by the Tineidae and the Tortricidae. The individuals of the Gelichiidae family are more numerous in Zaah Seeh and those of the Tineidae family are the most represented in Lepeh and absent in the other two localities. The town of Zaah Seeh has more individuals followed by Lepeh. In all localities there is no significant difference between families of the Lepidoptera order.

Table 5: Percentage of specimens of the different families of Lepidoptera order according to the 3 varieties of sweet peppers

\begin{tabular}{|c|c|c|c|c|}
\hline \multirow{2}{*}{ Lepidoptera } & Varieties & \multirow{2}{*}{ Ylusse } & \multirow{2}{*}{ Tibesti } & Total \\
\cline { 2 - 2 } \cline { 5 - 5 } & Simbad & & \\
\hline Gelichiidae & 16.89 & 0.99 & 32.56 & 50.44 \\
\hline Noctuidae & 2.55 & 0.39 & 3.08 & 6.02 \\
\hline Tortricidae & 0.19 & 0.18 & 0.13 & 0.50 \\
\hline Pieridae & 3.13 & 0.73 & 3.48 & 7.34 \\
\hline Tineidae & 7.51 & 1.76 & 8.36 & 17.63 \\
\hline Saturniidae & 3.41 & 5.39 & 1.67 & 10.47 \\
\hline Larves & 0.89 & 2.82 & 3.89 & 7.59 \\
\hline Total & 34.56 & 12.26 & 53.17 & 99.99 \\
\hline
\end{tabular}

Pearson's Chi-squared test: $\mathrm{X}$-squared $=50.514, \mathrm{df}=12, \mathrm{p}$-value $=$ $1.135 \mathrm{e}^{-06}$

\section{Order Hymenoptera}

The Hymenoptera Order consists of 19 families (Table 6). The district of Nkong-Ni is home to the most insects. Lepeh is in first place with 17 families followed by Tetop with 10 families and Zaah seeh with 7 families. Apart from the family of Elasmidae and Tenthredinidae which can only be seen in Tetop, all the other families of the Hymenoptera inventoried are found in Lepeh. Cimbicidae, Chalcidae, Diprionidae and Beythilidae are present only in the locality of Lepeh. Of the 4 families found in the Municipal lake, the Formicidae has the highest number of individuals followed by Apidae and Braconidae. Apidae are more numerous in Zaah Seeh and Megalodontidae is much more numerous in Tetop. The town of municipal lake has the largest number of individuals with the smallest number of families. There was a significant difference between the Formicidae family and the other hymenoptera families in Lepeh. In Tetop, there was a significant difference between the Ichneumoida family and other families. There was no significant difference between the arthropod families identified in Zaah Seeh.

In sum, in the localities of Zaah Seeh and Tetop, the 3 varieties of sweet peppers were grown. The average percentage suggests that arthropods are more sensitive to the "Ylusse" variety. But these percentages would be strongly influenced by the coexistence in the same plot areas of different varieties. This is confirmed by the percentages obtained by localities where Lepeh, of "Simbad" variety was the highest. In addition, the pepper plots in our study area were dotted with banana, cassava and fruit trees.

Table 6: Percentage of specimens of the different families of Hymenoptera order according to the 3 varieties of sweet peppers

\begin{tabular}{|c|c|c|c|c|}
\hline \multirow{2}{*}{ Hymenoptera } & Varieties & \multirow{2}{*}{ Ylusse } & \multirow{2}{*}{ Tibesti } & \multirow{2}{*}{ Total } \\
\hline & Simbad & & & \\
\hline Apidae & 1.98 & 1.33 & 14.94 & 18.25 \\
\hline Braconidae & 5.73 & 35.99 & 2.06 & 43.79 \\
\hline Beythilidae & 0.16 & 0.17 & 0.40 & 0.73 \\
\hline Celiopidae & 0.65 & 0.66 & 1.59 & 2.90 \\
\hline Chalcidae & 0.49 & 0.50 & 1.19 & 2.18 \\
\hline Cimbicidae & 0.08 & 0.08 & 0.20 & 0.36 \\
\hline Diaspriidae & 0.08 & 0.08 & 0.20 & 0.36 \\
\hline Diprionidae & 0.24 & 0.25 & 0.60 & 1.09 \\
\hline Eucharitidae & 0.16 & 0.17 & 0.40 & 0.73 \\
\hline Elasmidae & 0.07 & 0.58 & 0.01 & 0.67 \\
\hline Evaniidae & 0.19 & 0.75 & 0.16 & 1.09 \\
\hline Formicidae & 3.41 & 3.48 & 8.36 & 15.25 \\
\hline Ichneumoïdae & 0.26 & 3.09 & 0.00 & 3.35 \\
\hline Megalodontidae & 0.71 & 0.75 & 5.90 & 7.36 \\
\hline Phecidae & 0.08 & 0.08 & 0.20 & 0.36 \\
\hline Sceliomidae & 0.06 & 0.25 & 0.74 & 1.04 \\
\hline Vespidae & 0.00 & 0.41 & 0.07 & 0.49 \\
\hline Total & 14.35 & 48.62 & 37.02 & 99.99 \\
\hline
\end{tabular}

Pearson's Chi-squared test: $\mathrm{X}$-squared $=79.359, \mathrm{df}=32, \mathrm{p}$-value $=$ $6.702 \mathrm{e}^{-06}$

\section{Order Coleoptera}

Carabeidae, Cerambycidae, Chrysomelidae, Cicimdellidae, Coccinelidae, Curculionidae, Grinidae, Lycidiidae, Passolidae, Tenebrionidae and Tineidae families were colleted belonging to Coleoptera order. Tenebrionidae family is the most abundant followed by Coccinelidae. Lycidiidae and Tineidae are the least represented. The locality of Dschang lodged more insects of the Coleoptera 
order. Pearson X-squared test shows no dependence between different beetle families and the 3 varieties of sweet pepper $(\mathrm{X}$-squared $=18.006, \mathrm{df}=20, \mathrm{p}$-value $=0.587)$.

\section{Other orders present}

Three families of the Orthoptera were collected during this study. These three families are present in Lepeh. The Acrididae are absent in Zaah Seeh and the Tettigoniidae also at the Municipal Lake. The Gryllidae are only present in Lepeh. 65 individuals of the Thysanoptera were captured in Lepeh. Identifications are still being made in the determination of the families to which they belong. Two individuals from the Dictyoptera-Mantidae were collected in Lepeh during our investigations. Two Odonata individuals were captured: one in Lepeh and another in Zaah Seeh. 194 individuals of the Arachnida were collected and are mainly nonspecific predators.

\section{Discussion}

\section{Inventory of arthropods}

The study of sweet pepper entomofauna in the Menoua Division revealed the presence of 85 families of nine orders of the Insecta class. The work of Djiéto et al. (2014) ${ }^{[10]}$ indicates the same orders of the Insecta class in pepper plots in Yaounde. This diversity could be explained by the ecological conditions offered by peppers. Indeed, with its dense canopy, the pepper would create a microclimate that would be favorable to the swarming of many insects. The same findings were made by Kouonon et al. (2009) ${ }^{[21]}$ on Cucumis melo in Cameroon and by Koné et al. (2018) ${ }^{[20]}$ on zucchini in Côte d'Ivoire who found that the wider the leaves of the plant, the more numerous and varied the insects present. From the analyses of this study, it appears that the entomofauna of sweet pepper is largely dominated by the order of Hemiptera (Aphididae). Aphididae are lowmoving sucking stingers that attach to the organs of plants in colonies to feed on sap. These results corroborate those of Chougourou et al. (2012) [4] in the Municipality of Djakotomey in Benin, Ghelamallah (2016) ${ }^{[16]}$ in the Mostaganem region of northwestern Algeria and Fournier $(2010)^{[14]}$. They argue that Aphididae are major plant pests worldwide with negative economic consequences for agriculture. The order of Diptera is the most represented in family number. This result is similar to those of Djiéto and Aléné (2002) ${ }^{[8]}$ on the inventory of insects from market garden crops in Yaounde, Djiéto et al. (2014) ${ }^{[10]}$ on insect pests of $C$. annuum in Yaounde and those of Dial et al. (2015) ${ }^{[6]}$ on the incidence of fruit flies in Senegal. Prodiplosis longifila (Diptera-Cecidomyiidae) has been reported in pepper ( $C$. frutenscens), sweet pepper ( $C$. annum) and other companion plants in Colombia (Gagné and Jaschhof, 2014) ${ }^{[15]}$. This abundance could be explained by the need for fruit from Diptera larvae to complete their developmental cycle. Indeed, the period of this study corresponded to the flowering and fruiting phase of the pepper. $P$. longifila larvae consume leaf buds, flowers (ovaries and stamens) and small fruits of tomato plants, fruits of sweet pepper and flower buds of Tahiti lime (Hernandez et al., 2015) ${ }^{[18]}$. In this study, the Gellichiidae family is the most represented of the Lepidoptera order. At the present state of our knowledge, this family has not yet been reported on pepper in Cameroon, it is found on tomato. It has also been reported in Senegal on the updating of the entomofauna of vegetable crops in Lower Casamance by
Tendeng et al. (2017) ${ }^{[25]}$. This result would suggest that individuals in this family became polyphagous or would make pepper their secondary host. This is consistent with the results of Brévault et al. (2014) ${ }^{[3]}$ which suggests that Gelichiidae are microlepidoptera with a preferred host to tomato, but also found on peppers.

In Hymenoptera order, the most represented family is that of the Formicidae. The work of Djiéto and Aléné (2006) ${ }^{[9]}$ and Djiéto et al. (2014) ${ }^{[10]}$ points to the strong presence of Formicidae on peppers, a presence correlated with the high number of Aphididae providing honeydew as food. The study of pepper entomofauna in various localities revealed that Lepeh was lodged to the most arthropods. Hemiptera order was the most represented in number of individuals. The Aphididae family has the highest number in the same locality. This result could be explained by the low mobility of the Aphididae that live attached to the organs of the plant. The cultivation in Lepeh being under cover, the slightly higher temperature inside the shelter, combined with the absence of precipitation and winds that would detach these insects from the organs of the host plant, would start from the explanations of this abundance. These results can also be explained by the fact that under shelter, this culture is continuous and fallow-free. Also, crop rotation does not take into account plant families, which would result in the permanence of host plants for these insect pests. The locality of Zaah Seeh was the second largest in terms of abundance of individuals. The Drosophilidae (Diptera) family was the most represented. This could be explained by the fact that Zaah Seeh producers harvested their peppers at a very advanced ripening stage. The presence of the Tephritidae in this locality could be justified by the fact that Zaah Seeh has been a market gardening perimeter for several years and is located in a swampy area. These elements would promote adaptation to new host plants known as relay host plants. But in Lepeh, agriculture is under cover and Tetop is farming for the first time. Heumou et al. (2015) ${ }^{[17]}$ recorded Pyrallidae and Thephritidae in Cameroon on $C$. annuum. The Municipal Lake where there has been no application of chemicals is lodged to fewer families of insect pests and has more auxiliary families (Coccinelidae, Braconidae and Apidae), compared to Zaah Seeh and Lepeh where chemicals have been applied. Chemical destroy harmful and useful insects. Also, Cymbopocom citratus present around the plots would have an insect repellent effect on certain insects. The presence of Coccinellidae, natural enemies of the most important aphids, would reduce the populations of the latter. This last result corroborates Ferron's (1999) ${ }^{[12]}$ work in Algeria, which argues that Coccinellidae are often present where aphids are found. Overall, the presence of useful insects shows that biological control is possible and promising in Cameroon.

\section{Sensitivity of the 3 varieties of sweet pepper to the different arthropods}

The "Simbad" variety was the most frequented by the various arthropods. This variety would be the most appetizing and attractive than the other two varieties. Indeed, the darker green variety 'Simbad' has larger and meatier fruits than 'Tibesti' and 'Ylusse', which would provide more desired foods. The fruits of "Simbad" are harvested red unlike the others that are harvested green. This would give arthropods more time to develop. This idea is consistent with the work of Mannan et al. (2003) [29] 
which argues that the resistance or susceptibility of a plant may be due to biochemical characteristics such as chlorophyll, phenols and sugars. These results also show that, in addition to pests, many beneficial insects (pollinators, predators and parasitoids) coexist in pepper cultivation. Pollinating insects play a key role in productivity (Tchuenguem Fohouo et al., 2007) ${ }^{[24] .}$ Auxiliary (predators and parasitoids) contribute to the decline in pest populations, reducing the need to intervene to control their development (Heumou et al., 2015) ${ }^{[17]}$. Insect pests cause several types of damage to leaves (perforations) and fruits (perforations, spots, premature fall and rot). Some insects are vectors of disease (Hemiptera). However, there are useful insects such as parasitoids, predators and pollinators.

\section{Conclusion}

This study provided an update on the biodiversity of arthropods associated to peppers in Dschang-Cameroon. The arthropods inventoried belong to two classes Insecta and Arachnida. The insect orders identified are Diptera, Hemiptera, Hymenoptera, Lepidoptera, Beetles, Orthoptera, Thysanoptera and Odonata. The "Simbad" variety proved to be the most attractive with 2829 individuals out of a total of 3907 individuals of the Insecta class. Nevertheless, in-depth studies are needed on the main species in order to adapt crop protection patterns to suit the pests and auxiliaries actually present during cultivation. The results obtained constitute a database in the knowledge of the various pests of pepper cultivation in the locality of Dschang in Cameroon.

\section{References}

1. Albert S, Hastir P, Hance T. Agricultural biodiversity and carrot fly control. Gembloux's wildlife note 2003;50:3-8. [From French Translation]

2. Bopda A. Yaounde and the Cameroonian challenge of integration. Ed. CNRS, Paris 2003, 422. [From French Translation]

3. Brévault T, Sylla S, Diatte M, Bernadas G, Diarra K. Tuta absoluta Meyrick (Lepidoptera: Gelechiidae): A New Threat to Tomato Production in Sub-Saharan Africa. Afr. Entomol 2014;2:441-444.

4. Chougourou DC, Agbaka A, Adjakpa JB, Koutchika RE, Adjalian EJN. Preliminary inventory of the entomofauna of the tomato fields (Lycopersicon esculentum Mill) in the Municipality of Djakotomey in Benin. Int. J. Biol. Chem. Sci. 2012;6(4):1798-1804. [From French Translation]

5. Delvare G, Aberlenc HP. Insects from Africa and tropical America. Keys to family recognition. Prifas/cirad/Gerdat. Montpellier France 1989, 302. [From French Translation]

6. Dial A, Brévault T, Fall M, Diarra K. Incidence of fruit flies (Diptera, Tephritidae) in vegetable crops in the Niayes area of Senegal. Dakar: UCAD, Summary seminar DIVECOSYS on agroecological management of biotaggings in West Africa 2015, 1. [From French Translation]

7. Diatte M, Brévault T, Sall-Sy D, Diarra K. Cultivation practices influence attacks by two tomato pests in the Niayes in Senegal. Int. J Biol. Chem. Sci 2016;10(2):681-693. [From French Translation]
8. Djiéto LC, Aléné DC. Inventory of pests and useful market gardening in the Yaounde-Cameroon region, CIRAD-Yaoundé. 2002. [From French Translation]

9. Djiéto LC, Aléné DC. Diagnostic inventory of insects from some crops on suburban vegetable farms in the Yaounde-Cameroon region. PCP- Greater South Cameroon. Workshop proceedings presenting participatory research results. Yaounde 2006, 21-23. [From French Translation]

10. Djiéto LC, Heumou CR, Elono Azang PS, Aléné DC, Ngueng AC, Ngassam P, et al. Assessment of pest insects of Capsicum annuum L. 1753 (Solanaceae) in a cultivation cycle in Yaoundé. Int. J Biol Chem Sci 2014;8(2):621-632.

11. FAO. Growing greener cities in Africa. First status report on urban and peri urban horticulture in Africa. Roma 2012.

12. Ferron P. Integrated protection of cultures: evolution of the concept and its application. INRA 1999;19:19-28. [From French Translation]

13. Fouepe Fongang G. The changes in the bamiléké agricultural sector (Cameroon) studied through its actors: An analysis from the localities of Fokoué and Galim, Paris, doctoral thesis, Agro Paris Tech 2008, 416. [From French Translation]

14. Fournier A. Assessing winter survival of the aphid pathogenic fungus Pandora neoaphidis and implications for conservation biological control. Doctorate Thesis. Univ Eth Zurich 2010, 300.

15. Gagné RJ, Jaschhof M. A catalog of the Cecidomyiidae (Diptera) of the world, 3rd edn, digital version 2. Washington, USA: USDA 2014, 493. [Google Scholar].

16. Ghelamallah A. Study of aphids from vegetable crops and their parasitic complexes in the Mostaganem region (Northwestern Algerian PhD in Agricultural Sciences: Crop Protections, Abou berk Belkaid d'Algerie 2016, 157. [From French Translation]

17. Heumou CR, Djiéto LC, Aléné DC, Elono Azang PS. Diversity and Agronomic status of tomato and pepper fruit pests in two agroecological zones of Southern Cameroon: Western Highland and the Southern Plateau of Cameroon. Afr. J Agri Res 2015;10(11):1224-1232.

18. Hernandez LM, Guzman YC, Martinez-Arias A, Manzono MR, Selvaraj JJ. The bud midge Prodiplosis longifila: Damage characteristics, potential distribution and presence on a new crop host in Colombia. Research 2015;4:205. DOI 10.1186/s40064-015-0987-6

19. Kaffo C. Vegetable crops in the mountains of western Cameroon. Cahiers d'agriculture 2005;14(6):27-64. [From French Translation]

20. Kone K, Tuo Y, Yapo LM, Kouakou HK. Entomofauna of Zucchini (Cucurbita pepo L.) in the rainy season, in Korhogo, northern Côte d'Ivoire. Int. J. Biol. Chem. Sci 2018;12(3):1286-1297. [From French Translation]

21. Kouonon LC, Jacquemart AL, Zoro Bi AI, Bertin P, Baudoin JP. Reproductive biology of andromonoecious Cucumis melo subsp. Agrestis (Cucurbitaceae). Annals of Botany 2009;104(6):1129-1139.

22. Nimona Fufa Hunde. Yield response and nutrient use efficiencies of hot pepper (Capsicum annuum L.) to inorganic fertilizers in Ethiopia: A review article. Int. J Res. Agron. 2020;3(1):25-32. 
23. Tchékoté H, Nguedia MM, Siyapdje EC. Land ownership, agricultural practices and environmental issues in Bafou-Nord in the Bamboutos Mountains (West Cameroon). 2018, Belgeo consulted on 2019. [From French Translation]

24. Tchuenguem Fohouo FN, Djonwangwé D, Messi J, Brückner D. Exploitation of flowers from Entada africana, Eucalyptus camaldulensis, Psidium guajava and Trichillia emetica by Apis mellifera adansonii in Dang (Ngaoundéré, Cameroon). Mr. Cameroon. J. Exp Biol 2007;3(2):50. [From French Translation]

25. Tendeng E, Labou B, Djiba S, Diarra K. Updated the entomofauna of vegetable crops in Lower Casamance (Senegal). Int. J. Biol. Chem. Sci 2017;11(3):10231028. [From French Translation]

26. Willcox JK, Ash SL, Catignani GL. Antioxidants and prevention of chronic disease. Crit Rev Food Sci Nutr 2004;44(4):275-95.

27. Wolfgang D, Werner R. Insect guides, description, habitat and manners. Edition: Delachaux et Niestlé S.A, Paris 1992, 237. [From French Translation]

28. Yolou FI. Urban market in Parakou in North Benin and its economic profitability. Int. J Innovation Sci. Res 2015;19(2):290-302. [From French Translation]

29. Mannan MA, Begum A, Rahman MM, Hossain MM. Screening of Local and Exotic Brinjal Varieties/Cultivars for Resistance to Brinjal Shoot and Fruit Borer, Leucinodes orbonalis Guen. Pak. J Biol. Sci. 2003;6(5):488-492. 